IRA-International Journal of Education \& Multidisciplinary Studies

ISSN 2455-2526; Vol.14, Issue 03 (March, 2019)

Pg. no. 37-44.

Institute of Research Advances

Institute of

http://research-advances.org/index.php/IJEMS

\title{
Evangelizing to the Somali Muslims of Eastleigh: Interrogation of A.I.C. Christians Preparedness in Nairobi Central Region, Kenya
}

\author{
Philemon Kipruto Tanui ${ }^{1}$ \& Josephine K. Mutuku Sesi ${ }^{2 \#}$ \\ ${ }^{1,2}$ Africa International University, P.O. BOX 24686-00502, Karen, Nairobi, Kenya. \\ "corresponding author. \\ Type of Work: Peer Reviewed \\ DOI: http://dx.doi.org/10.21013/jems.v14.n3.p1
}

\section{How to cite this paper:}

Kipruto Tanui, P., Mutuku Sesi, J. (2019). Evangelizing to the Somali Muslims of Eastleigh: Interrogation of A.I.C. Christians Preparedness in Nairobi Central Region, Kenya. IRA International Journal of Education and Multidisciplinary Studies (ISSN 2455-2526), 14(3), 3744.doi: http://dx.doi.org/10.21013/jems.v14.n3.p1

(c) Institute of Research Advances.

This work is licensed under a Creative Commons Attribution-Non Commercial 4.0 International License subject to a proper citation to the publication source of the work.

Disclaimer: The scholarly papers as reviewed and published by the Institute of Research Advances (IRA) are the views and opinions of their respective authors and are not the views or opinions of the IRA. The IRA disclaims of any harm or loss caused due to the published content to any party.

Institute of Research Advances is an institutional publisher member of Publishers International Linking Association Inc. (PILA-CrossRef), USA. The institute is an institutional signatory to the Budapest Open Access Initiative, Hungary advocating the open access of scientific and scholarly knowledge. The Institute is a registered content provider under Open Access Initiative Protocol for Metadata Harvesting (OAI-PMH).

The journal is indexed \& included in WorldCat Discovery Service (USA), CrossRef Metadata Search (USA), WorldCat (USA), OCLC (USA), Open J-Gate (India), EZB (Germany) Scilit (Switzerland), Airiti (China), Bielefeld Academic Search Engine (BASE) of Bielefeld University, Germany, PKP Index of Simon Fraser University, Canada. 


\begin{abstract}
Evangelistic work among the Muslims has never been easy. The Gospel of the Lord has been hindered from reaching the Muslim devout by a number of factors found by expected Christian Ministers along with their mission. As a result, missionary work has realised little impact among Muslims. Specifically, less has been achieved by the Christians among the Eastleigh Muslim community. This is attributed to lack of preparedness among the Christians. This paper, therefore, endeavoured to interrogate the extent to which African Inland Church Christians in Nairobi Central Region are prepared to evangelize to Muslims in Eastleigh, Nairobi with an aim to recommend best practices in winning Muslim souls to Christ. A sample of 12 informants was drawn and interviewed. Ethnographic interviews elicited important data that was used to generate themes and sub-themes for analysis after which conclusions were made. It was found that many Christians know very little about other religions particularly Islam. Thus, it was not easy to convince the Muslims as their attempts would lead to heated and endless debates. The authors recommend that the church should create mission awareness by encouraging frequent interactions between her members and the Somali Muslim Community in Eastleigh.
\end{abstract}

Key words: Christian, Muslim, Islam, Mission, Gospel, Eastleigh, Kenya.

\title{
Introduction
}

Notably, the A.I.C-Kenya churches give finances to support mission work to the unreached communities twice a year on the first Sundays of May and October. However, even in churches located adjacent to Muslim communities like in Eastleigh, little attempt has been made on reaching out to Muslims with the gospel of Jesus Christ. The question to ask is: are A.I.C. Christians living around these Muslims well prepared to evangelize to this group of people? Preparedness in this context denotes knowledge of other religions; understanding of ways of coming to the saving knowledge of Jesus Christ; understanding different ways of growing in faith, and witnessing to members of Islam.

Under the A.I.C-Kenya, Nairobi Central Region, there are three local churches: A.I.C Ziwani, A.I.C Ngara, and A.I.C Eastleigh Section III with a membership of about 7,000, 150, and 100 respectively. The average distance from each of these three local churches to where the Somali Muslim community live and do their businesses is about $5.5 \mathrm{Km}$. Undeniably, the presence of the church has been in this area for decades; the A.I.C Ziwani, A.I.C Eastleigh Section III, and A.I.C Ngara churches were started in the years 1958, 2015, and 2016 respectively.

\section{Literature Underpinning}

\section{Understanding Islam}

Little is known about the Muslims and their religious identity by the majority of Christians, particularly in Kenya. In his book, Islam Among the Swahili in East Africa, Kim notes with insight that "in general, Islamic Studies have been confined to classical type of study that has focused mainly on dealing with the ideologies of Islam rather than studying the people (Muslims) who hold these beliefs and live under their influences" [1]. His proposition implies that most Christians do not know how Muslims live up to what they profess in their daily lives. Christians only read in books about the Muslims and have not yet interacted with them.

To understand "the local Islamic culture" one has to comprehend "the ways in which Islam has been applied to and integrated to a particular local context" [1]. For the church to be effective in reaching out to the Muslims with the Gospel, Kim's sentiments must be given attention if the church has to make an impact in her evangelistic work. “Are we, however, better informed now concerning Islam itself?"[2]. This question was directed to the German people concerning Muslim immigrants in their country. As well, A.I.C churches and other denominations, even today, can ask themselves the same question.

While exploring on the same thought, Kim argues that in order for one to understand Islam, he has to consider Muslims in a particular context [1]. Context is essential some communities who have accepted and practice Islam have integrated Islam into their cultures giving birth to Folk Islam. Folk Islam is also known as popular Islam "which incorporates various forms of the occult and mystical elements of religious content" [3]. Trimingham points out that "Islam does not explain the religion of any Muslim any more than Christianity does that of any Christian" [4] . He further adds that "a person's or community's religious consciousness is both less and more than the religion professed" [4]. These sentiments are actually true in the sense that we see most of the Muslims practice a different thing from what they profess. The authors' context is in Eastleigh, Nairobi. 
As we look into the culture and religious life of Muslims, Caner and Caner [5] argue that "any major religion must first be seen through the eyes of its founder". This is a true statement because it entails the teachings of that founder and his or her lifestyle. Muslims look up to Muhammad who is their founder just like Christians to Jesus who is their Saviour. Having the right kind of understanding of Islam calls for the church to know who Muhammad was and how he propagated Islam and its beliefs.

Admittedly, it is important to learn about the background of the leader, but Christians should also seek to understand the ultimate authority that the leader ascribes his powers. Caner and Caner [5]note that "according to Islam, the Qur'an is the final revelation from Allah" [p.83]. Alongside the revelation from Allah, Muslims also believe in the Hadiths. Evidently, the source of power and authority, to a faithful Muslim, is the Qur'an and the Hadith.

A Muslim based on the teachings of the Qur'an and the Hadith believes that there is no other God but Allah, and Muhammad is his final messenger sent with a warning to the people of the world. Muslims also believe that those who don't accept Islam are infidels that await the judgment of Allah unless they otherwise heed to Allah's message through his final prophet. A Christian doing evangelism to Muslims must have knowledge of how the Qur'an and the Hadith view the Bible. This is essential to the Christian evangelist or missionary to adequately respond gently and accordingly to the questions that might be raised by a Muslim devout.

\section{The Mandate of the Church in Reaching Out to the World with the Gospel}

Christians have been called by God to share the good news to all people of the world. Nehls [6] posits, "the Great Commission of our Lord Jesus Christ compels all his disciples at All times to reach out to all people everywhere" [p.3]. In the Old Testament, God asked Isaiah the prophet “...Whom shall I send? And who will go for us?" (Isaiah 6:8). Isaiah responded by saying “...Here am I, Send me” (Isaiah 6:8). The church should be ready and willing to be sent by the Lord of the harvest to his field because it is ripe and is awaiting harvesters.

In the New Testament, Jesus commanded Christian to go out to the world and reach out to all people and share the gospel to them. His promise to the disciples was succinct and clear, "Surely, I am with you always" (Matt. 28:20). Just before his ascension, Jesus charged his disciples that "you will be my witnesses in Jerusalem, and in all Judea and Samaria, and to the ends of the earth" (Acts 1:8b). The individual Christians and the church have no option but to heed to the calling to go to the world and win souls for Christ. In Matthew 28:18-20, Jesus commanded the disciples to go and make disciples of all nations. Hiebert [7] comments, "This mission is ultimately God's and we are part of that mission" [p.17](1985, p. 17). If the church is part of God's mission, then the church should be ready to go out without any further delay. Nabwera[8] observed that "the presence of Muslims in Kenya makes Muslim evangelism important". This is part of the mandate of the church, to reach out to all people with the Gospel of Jesus Christ.

Evidently, it is therefore imperative for the church to fulfil the great commission which was set forth by the Lord Jesus Christ. The A.I.C. churches situated around Eastleigh in Nairobi have a greater privilege because the 'world' has come closer even to her doorstep. The presence of the Somali community in the church's neighbourhood is both an opportunity and a challenge to the body of Christ in fulfilling its God-given mandate which is to step up and share the good news of salvation to this community.

\section{Availability of Designed Teachings and its Sensitization of Muslim Evangelism}

As we have just seen that all Christians are commanded to take the gospel to all nations, the question of preparedness solely lies with the pastorate or leadership of the church. Nehls [6] (1988, p. 4) quotes Andrew Murray who says, "the enthusiasm for the kingdom of God is missing because there is little enthusiasm for the king". Who can rejuvenate this kind of enthusiasm for the work of the Lord apart from the pastors, missionaries and leaders of the church? Enthusiasm for the work of the Lord goes hand in hand with the level of spiritual growth of the Christian. The love for God should make the church to emulate Him when He first loved us while we were still sinners. The church should at the same time love the Muslims and that forms the motivation for taking the gospel to them (Muslims).

Further, Nehls [6]argues that "a burden is no burden, as long as it is on the ground. Only when it is on our shoulder, i.e. when a thing is lifted up, it is a load" [p.4]. Someone should cause the church to have that burden of reaching the Muslims with the gospel. In Romans 10:14-17, Paul wonders how people can hear without anyone preaching, and how preaching can happen unless someone is sent. The church leadership is responsible for educating the church about the need to share what it enjoys to the world of Muslims. 
In Muslim engagement, John Gilchrist [9] in his book, Facing the Muslim Challenge, outlines five important approaches which the church can use while witnessing or engaging in an argument with them. In his closing remarks as pertaining to these approaches, Gilchrist says that "be sure that all you do and say is done in a spirit of genuine love for them" ]. This is a true assertion because if love is not at the centre of all things, then the whole work will be a burden that will be avoided rather than a burden that should be embraced for God's sake.

In a whole chapter, Nehls [6] has presented several practical sides of Muslims evangelism that will help the evangelist, the pastor, and the missionary in a step-by-step approach while presenting the gospel of Christ to a Muslim person. Just to highlight a point in one of the approaches of preparation, Nehls warns the evangelists that they should "first learn the basics of his cultural background, his religion and his disposition of to the Christian faith but also how to actually approach him, reason and communicate with him" [p. 35].

Gilchrist [9] further admits that "Muslim evangelism is one of the toughest fields of Christian witness" [p.4] because of the ideologies and doctrines that the Muslim person has been fed with. However, he outlines four approaches that have worked in Muslim evangelism. These approaches can only be useful if the church or evangelists are taken through them in readiness to share the gospel with Muslims. Fernando [10], highlights comprehensive approaches for reaching people of other faiths. Materials that are to be used for evangelistic among the Muslims are so many; it is the readiness of the church that is in question. Cate and Downey [11] emphasisethe power of love in reaching out to the Muslim women. It is "neither fluency in the language, nor possessing numerous gifts" [p.102].

There are also some steps that the navigators have used in the Middle East in their ministry to students [12]. These steps can work well if the evangelists, pastors and missionaries of the church can embrace them and use them in a manner that can bring about change in the lives of the recipients.

\section{Methodology}

This article interrogates preparedness of Christians in their mission work for the Somali Muslim community in Eastleigh by A.I.C Nairobi Central Region. A.I.C. Nairobi Central Region consists of churches that surround Eastleigh whereby a majority of the Somali Muslim community reside. This Region is one of the administrative structures of the A.I.C. church that is chaired by an ordained minister. Eastleigh is the Eastern part of Nairobi which is about six kilometres from the Central Business District of Nairobi City. Majority of the population of this place are business people from the Somali Community.

The A.I.C Nairobi Central Region has a population of about eight thousand congregants and it would be impossible to conduct the study without sampling it to a manageable size of informants. Twelve (12) informants were therefore selected using systematic sampling. The informants were sampled from different leadership groups which are under the church's Christian Education Department (C.E.D). The informants had a different level of experience based on the years they have been consistent members of their local churches.

The total population of the leaders were divided in each sampled church by the intended number of persons to be interviewed. One person was interviewed in each leadership group from the churches from the following leadership categories: Local Church Council (aged between 35-70 years), Christian Men Fellowship (aged between 35-65 years), Christian Women Fellowship (aged between 25-55 years), Youth and from the Choir (aged 18-34 years). The authors explained to the informants about the topic he was researching on before the interview process.

The ethnographic interview was used to collect primary data that would highlight the factors hindering evangelistic work among the Somali Muslim community in Eastleigh.

After collecting the data, it was transcribed then recorded and saved with different file names which helped to carefully examine the data during coding of themes, ideas and patterns. approaches, as given by Mugenda [13], were used to analyse the data. These processes involve: editing and cleaning up the transcribed material; creating distinct categories, themes and patterns; establishing relationships among them; and analysing and interpreting information. It is done by closely evaluating the usefulness of the information in answering the research question and writing the report.

\section{Findings and Discussion}

The Great Commission that Jesus gave his disciples and the church today in Matthew 28:18-20 is a mission that every confessing and practising Christian must take part in as far as reaching the Somali Muslims in Eastleigh is concerned. The Christian who will be involved in this great commission must be prepared adequately for this 
great and noble task. To understand the extent to which Christians are prepared for missionary work, the authors probed the informants on their knowledge of other religions apart from Christianity, their understanding on different ways of coming to the saving knowledge of Jesus Christ, different ways of growth in faith, and witnessing to the Somali Muslims. The findings are recorded in the following sections.

\section{Knowledge about Other Religions}

The authors sought to know whether the informants knew what other religions believe in and their objects of worship. From the findings, about eighty per cent of the informants does not know the basics of other religions except for scanty information about Islam and Hinduism. Joyce and Patrice mentioned that Hindus have put their faith in cows as Roselyn believed that "Hindus have their own god". Suzy reported that she used to have a colleague who was a Bahai. She further said that her friend was so reserved and did not want to interact with people at all.

From the foregoing responses, it is evident that the informants do not have adequate knowledge of other religions apart from what they believe. Knowledge of what other religions believe and worship for a Christian is necessary for evangelizing to other religions like Islam. Having knowledge about other religions will help the Christians understand effective approaches that can help in initiating and sustaining a conversation with people of other faiths. It will also help the person witnessing to acquire more knowledge about other religions so that he or she can be in a better position to preach the gospel. The premises and approaches for reaching out to Muslims are mostly applied across the board. Jesus used such an approach when he had an encounter with a Samaritan woman at Jacobs' well in Sycar (John 4:1-27).

\section{Understanding the ways of Coming to Jesus Christ}

The Bible in Romans 10:14-17 talks of a person who is preaching to someone who will, in turn, hear the message and believe by calling on the name of the One whom God has sent, Jesus Christ. The preaching of the gospel also entails someone being sent. The authors posed a question to the informants on how they came to believe in Jesus Christ. This was categorically asked to establish whether the informants can reciprocate what they have received from others which led them to become Christians.

It was found from the informants that each one had heard the message of Jesus Christ from someone who had preached to them either in a church meeting, camp meeting, and home cells or in high school. Eli who is one of the informants said, "the second time I went to attend my Mum's home Cell Group, I gave my life at this fellowship because I felt that the message was speaking to me".Mwanzia said that he used to sneak to attend Sunday school classes because his father was strict, and he could not allow anyone to attend any church service, not even the Sunday school. He further says that it was in one of the Sunday school classes that he gave his life to Jesus Christ.

Suzy is one of the informants who gave her life to Jesus Christ after so many years of her church attendance. She confessed that it was until when she lately joined one of the Christian Education Department (C.E.D) groups in the church that she begun to get to understand what salvation meant to her through the Bible study sessions that they used to have in the group. The informants who got the chance to hear the word of God at an early stage in life have had the chance to minister to many other people.

The Somali Muslims who reside in Eastleigh need to hear the gospel of Isa; therefore, someone should accept to be sent to them with the good tidings of salvation in Jesus Christ. The fact that someone spoke the word of God to the informants in different times of their lives and in their homes, someone should speak the word of God to the Somali Muslims as well. Fear of unpreparedness and fear of the unknown are some of the factors that have affected the evangelistic work among the Somali Muslims in Eastleigh by the members of the A.I.C Nairobi Central Region. Fear will scare unprepared Christians not to see the need to reach the Somali Muslims.

The church should prepare her congregants by equipping them with the word of God so as to grow in the Lord and be ready to have their feet fitted in readiness that comes with the gospel of peace (Eph 6:15). The focus of the church should also consider equipping children and the teenagers, the generations who have been victims of all social evils in the society. 


\section{Ways of Spiritual Growth}

The spiritual growth of a believer is very essential because of the impact that it has on the church and to the rest of the world. Newton [14] writes, "A strategy for growing toward Christlikeness must be based on the actual ways that people grow and develop spiritually" [p.1]. It is with this regard that the authors sought to find out whether the interviewees grow in their faith. This growth will directly affect their witnessing not only to the Somali Muslims but also to other people who have not yet heard the word of the Lord.

It was found that all the interviewed were engaged in either one group or more than one groups in the church. The groups that the informants participate in are the Bible study, the choir, home cells, prayer groups, and family Bible studies at home. The informants also attested that they grow through the sermons and teaching from their pastors every Sunday.

Rosyln said, "I grow as a Christian by fellowshipping with other Christians, by praying, by reading my Bible at home, through the choir, and as I lead my group". From her response, it can be seen that Christians also grow as they serve in their various groups. Newton [14] supports this proposition by saying, "Young Christians grow spiritually because they are well nourished by the food God's word provides" [p.43]. It is the word of God that makes the informants and their entire respective churches to grow to the point that they can form many other groups like the prayer fellowships.

It was also observed that some of the informants have benefited a lot from the fellowship groups they have in their churches as far as their spiritual lives are concerned. Janet said that she had not known what people do in overnight prayers (Kesha) until she attended one. She further said that out of this night prayer vigils, she has known how to pray for others and herself as well.

From their responses under this section, it can be deduced that spiritual growth will propel the need to reach other people (Somali Muslims) with the gospel of Jesus Christ. The entire church of the A.I.C Nairobi Central Region has the opportunity to reach out to the Somali Muslims through her members. This can be done by strengthening the existing groups so that they can be involved in mission work.

\section{Christian Witness}

As Romans 10:17 teaches, faith comes by hearing the message and this message is heard through the word of Christ; so, the message that has been heard should be proclaimed to other people for them to hear and believe in Jesus Christ. A Christian will not be in a position to witness when he or she has not had a remarkable spiritual growth as a Christian. Christians are compelled to witness because there is something unique that has happened to them and are ready to witness or share to the world.

From the responses, the authors learnt that majority of the informants had witnessed in one way or another to more than five people; although from the interviewer's observation, it seemed that only a few of them have actually led some people to the saving grace of Jesus Christ. Arthur who is one of the informants said, "I have preached to them, but I have not followed them". Suzy also claims, "I do not know of a particular person who has come to Christ but I can say from the time I got saved, my family members came to Christ and they include my children and my husband".

In this part, the majority of the informants have been involved in evangelistic work elsewhere which was organized by their churches during Easter Holidays. From these evangelistic campaigns, it is quite difficult to ascertain whether someone has fully accepted Christ. Witnessing to the Somali Muslims requires a different approach from that which the informants have been using or used to. The informants also seemed to have been comfortable with their ways of doing evangelism to people whom they are used to. In this regard, the church needs to improve or change the methods they use in doing missions and to factor in other approaches that will be used to reach the Somali Muslims in Eastleigh.

\section{Witnessing to the Somali Muslims}

From the observations and interviews, the authors noted that most of the informants have not yet taken any step to share the gospel message to the Somali Muslims because of the previously mentioned reasons.

Majority of the informants had their own reservations as to why they have never witnessed to Somali Muslims. For example, Arthur elusively responded, "No, I will minister to them if I get the chance". Elly who admitted that he has interacted with so many Somali Muslims said he has tried to reach out to them but found it to be so 
hard because of resistance. He further claimed that one of the Somali Muslim vowed not to hold the Bible and if he holds, he will tear it down or burn it. Dave, who supplies bread to some Somali business men and women, claimed that the Somali Muslims are very resistant to the Gospel message.

Suzy admitted she has had a discussion with a Muslim, but because of her first experience, vowed never to talk to any Muslim in her lifetime. Upon further probing, she said, "I realized that at the end of the day, you end up with lengthy arguments".Many reservedly think that "Christians would rather hold their peace or keep themselves that appear to be opposing the Muslim beliefs" [15, p. 44].

From the above findings, the authors noted that the informants fear to reach out to the Somali Muslim community because they do not want to engage in heated debates. Perhaps the arguments can even be embarrassing because of the level of unpreparedness to face such a huge task. Mutunga[16] reports, "Somali Muslims like arguing and at times when you seriously challenge some of their religious teachings, they become angry and can turn to be aggressive" [p.35]. Evidently, there is a fear of intimidation and terrorism. As previously mentioned, the informants fear to fall victims of attacks by the so-called Al-Shabaab militants who are believed to have their agents in Eastleigh. Carrier [17] says that "Eastleigh has long been seen as a hub for such recruitment, especially through the Abubakar Mosque on the sixth street, whose clerics had some initial sympathy with the Al-Shabaab-supported simple implementation of the Sharia" [p.226].

Further, the informants have been used to their comfort zones and a lifestyle that is free from any kind of engagement that would trouble them. Reaching the Somali Muslims would mean that their way of doing things will change as far as witnessing is concerned. In order to witness to the Somali Muslims, one should undergo training sessions. Mutunga [16] reported that some of his informants had difficulties in their dialogues because of lack of training. The authors of this article are in agreement with Mutunga that one of the ways to witness to the Somali Muslims is through dialogues by Christians who do not have uncertainties in their lives and are ready to move and engage the Somali Muslims with the word of God.

\section{The Need to Witness to the Somali Muslims}

The Somali Muslims are part of the wonderful people whom Christ died for. Therefore, there is a need to witness to them. This need came out clearly from the informants interviewed that the Somali Muslims should be witnessed. The knowledge of other religions, spiritual growth and witnessing sections elicited responses that revealed the need to witness to the Somali Muslims in Eastleigh. All the informants agreed that the Somali Muslims urgently need to hear the gospel. This was arrived at when the Christians interviewed retrospectively thought and remembered that someone had offered to preach to them while they were still sinners (Romans 5:8).

Witnessing to the Somali Muslims is not an easy task; it requires a lot of courage and determination. All of these should be enveloped with love because there is no other way that care is shown other than through love. Love cannot be expressed without the constant nourishment of the word of God in the life of a Christian. Having known about all the discussed key points, the authors inquired if the informants were willing to minister to the Somali Muslims.

Since Somali Muslims are generally feared by Christians in the Eastleigh area because of their worldview which is informed by the Qur'an and the Hadith, understanding their way of doing things and the general lifestyle is very crucial for a Christian witness. Concerning worldview, Mutunga[16 notes that "In addition to preaching the gospel, there is a need for Christians to understand the worldviews of the Somali Muslims for it contributes to a fruitful dialogue'"[p.44].

\section{Conclusion}

It is evident from the findings that the church members are not evangelizing the Somali Muslim community because of the lack of teachings that are based on reaching the community. This may never take the church any further step in her quest to reach the entire world with the Gospel of Jesus Christ. The absence of teachings has also given birth to the notion from the church members that the Somali Muslim community is hard to deal with people and that they cannot convert to Christianity from Islam.

It is quite encouraging that nearly all the informants confessed of having been led by someone to the saving knowledge of Jesus Christ at some various points in their lives. However, it is a fact that they all consented that their Somali Muslim neighbours need such an experience to know Jesus and believe in Him. This can only be done by people who are deeply rooted in the word of God and are in a position to withstand all kinds of challenges they encounter as they minister in the church through existing and new programs. Just as the 
informants are witnessing to other people who are not from the Somali Muslim community, they are also obliged to share the same tidings to their neighbours as well.

\section{Recommendation}

The A.I.C Nairobi Central Region should, therefore, embrace mission work. This is because there is a great ripen harvest of souls among the Somali Muslim Community in Eastleigh awaiting the harvesters to roll up their sleeves and get into the field. This also calls for the church to create mission awareness by encouraging frequent interactions between members of the church and the Somali Muslim Community in Eastleigh.

In addition, the Christians should be prepared well by the pastors, evangelists and the church leaders so that they gain enough knowledge and courage to preach the truth of the gospel to Muslims. Training and teachings must be strengthened if evangelism to the Muslim community is to be successful.

Christians too should practise what they learn in church. They should do to their Muslim brothers and sisters what the Christian fraternity did to them. For instance, if someone had preached to them so that they understand what Gospel of truth is, then they should take it upon themselves to preach to others about the same message of salvation they received.

\section{The implication for Research and Practice}

As the A.I.C Nairobi Central Region church creates mission awareness to her members in reaching the Somali Muslim community with the gospel, her members become courageous. Also, awareness makes them treat the Somali Muslim community as part of God's creation whom Christ died for as well. The church will not only experience spiritual but also a numerical growth as well because more souls will be harvested for the honour and glory of God.

\section{References}

[1]. Kim, C. C. (2016). Islam among the Swahili in East Africa (2nd edn.). Nairobi: Acton Publishers.

[2]. Schirrmacher, C. (2008). Islam and Society (Vol. 2). Germany: World Evangelical Alliance.

[3]. Nehls, G. (1991). Premises and Principles of Muslim Evangelism. Bombay: GLS Press.

[4]. Trimingham, J. S. (1986). The Influence of Islam upon Africa (2nd edn.). London: Longman Librairie du Liban.

[5]. Caner, E. M., \& Caner, E. F. (2002). Unveiling Islam. Nairobi: Evangel Publishing Ltd.

[6]. Nehls, G. (1988). The Great Commission, You and the Muslims (Rev. edn.). Bellville, South Africa: Evangelical Missions Press.

[7]. Hiebert, P. G. (1985). Anthropological Insights for Missionaries. Grand Rapids, Michigan: Baker Book House.

[8]. Nabwera, J. P. 2008. A Critical Survey of Missionary Attrition among African Missionaries in Muslim Evangelism in Kenya: The Case of the SheepfoldMinistries. Thesis (M.A. Missions) Nairobi Evangelical Graduate School of Theology, Nairobi, Kenya.

[9]. Gilchrist, J. (1999). Facing the Muslim Challenge: A Handbook for Christian-Muslim Apologetics. Cape Town: Life Challenge Africa.

[10]. Fernando, A. (200). Sharing the Truth in Love: How to Relate to People of Other Faiths. Grand Rapids, MI: Discovery House.

[11]. Cate, M. A.,\& Downey, K. (2002). From Fear to Faith. California: William Carey Library.

[12]. Kamau, W. (2005). A Study of Eastleigh Fellowship Center's Muslim-Youth Ministry Methods from a Christian Cross-Cultural Perspective (Master's Thesis). Nairobi Evangelical Graduate School of Theology, Nairobi, Kenya.

[13]. Mugenda, O. M. (1999). Research Methods: Quantitative \& Qualitative Approaches. Nairobi: ACTS Press.

[14]. Newton, G. C. (2004). Growing toward Spiritual Maturity. In Biblical Essentials Series. Wheaton, Illinois: Crossway Books.

[15]. Strohbach, D. W. (2012). Christian Relation with the Muslims and Its Implications for Christian Witness: A Case Study of Calvary Chapel Mombasa, (Master's Thesis). Africa International University, Nairobi, Kenya.

[16]. Mutunga, T. K. (2016). An Investigation into the Effects of Dialogue in Christian Evangelism to Somali Muslims in Eastleigh, Nairobi in Kenya (Master's Thesis). Nairobi Evangelical Graduate School of Theology, Nairobi, Kenya.

[17]. Carrier, N. (2016). Little Mogadishu, Eastleigh: Nairobi’s Somali Hub. New York: Oxford University Press. 